\title{
Some Issues Concerning Values in Measuring Achievements in Education
}

\author{
Mátyás Turós*
}

\author{
Received: November 9, 2018; received in revised form: February 7, 2019; \\ accepted: February 10, 2019
}

\begin{abstract}
:
Introduction: This study analyzes the mode of value transmission and those set of values that promote the measurement of educational outcomes. Purpose: The focus of this contribution is to discover helpful guidelines for a set of educational values.

Methods: In the present study, we applied source analysis as a traditional research method in the philosophy of education.

Conclusion: We would like to point out that education is the observation, consideration and formation of needs and, at the same time, pedagogy is at least as a regulating as a descriptive kind of an activity. The ideal educational system of methods and objectives are neither open nor closed, it only contains elements that provide possibilities for the individual to fulfill requirements in quantity and quality according to their aptitude. On the other hand, it assures forming behavior and socialization simultaneously.
\end{abstract}

Key words: socialization, education, norms, values.

\section{Introduction - normative and norm-critical concepts in values and in value transmission}

A key topic in educational theory and a fundamental paradox is how to derive and control the legitimacy of the transition between the individual and the social, the natural and the spiritual. It is a fact that the mechanism of negotiations between the individual and the social organizations operates in a bureaucratic, institutional and organizational network and turns out to be far too complicated in the social, technical and economic systems in a democratic society. For this reason, a person conforming to norms can realize their intentions in cooperation with other people. A straightforward interpretation following this is that socialization requiring cooperation creates the ability in an individual to come to accurate social and personal predictions in a way that this ability helps the

\footnotetext{
* Mátyás Turós, Doctoral School of Pedagogical Sciences, Eszterházy Károly University, Eger, Hungary; turosmatyas@gmail.com
} 


\section{Acta Educationis Generalis \\ volume 9, 2019, issue 1}

individual to avoid or keep unpleasant sanctions and consequences at a tolerable level in one's personal life. The majority of social, societal norms producing patterns keep the possibility of failure low and maintain stability in one's life. School is basically the informal, individualized system of conditions in a family's social space and it necessarily transmits norms and values while serving as a transition toward the formal, social system of conditions. Very often, conceptions of powerful organizations of society represented by institutional education are realized in norms and they are to play a significant role in preserving the stability of society and in enhancing a peaceful coexistence and personal success. In this respect, one of the most important objectives of education is to improve the ability in the student to make individually successful, accurate, and socially valuable predictions as a social agent. Furthermore, the objective of educational institutions during the process of transmitting values and fostering personal development is to enable the individual gradually to carry out their social tasks with an acceptable human behavior. In the process of value transmission, norms that are transmitted are to be regarded as permanent within time and space but not within the different societies or not as being timeless and universal. Fulfilling the function of socialization in education is essential but applying norms over the boundaries of legal practice reduces the impulses coming from the individual toward the community, and extreme normativity creates antipathy and later resistance. Finally, methods of pedagogy overestimating socialization agents, interpreting themselves coming from authority, belong here as well, which, by connecting the concepts of education and community too closely and directly together, tend to forget about the individualizing, humanizing and moralizing function of education producing destructive results (Mészáros, 2015; Trencsényi \& Nagy, 2016, pp. 88-89). It is presented through:

1) social level-straightforward, deterrent examples of oppressive, repressive social systems;

2) institutional level-ineffectiveness in the transmission of values, because educators who praise their professional autonomy are not willing to accept the detailed description of procedures reducing the diversity of pedagogical situations.

\section{The criticism of criticism}

Experiments trying to overcome the basically normative approach began in the 19th century (Dilthey, [1888] 1962) until the birth of the Sciences of Education. In the 20th century pedagogy, the educational process already had at least three concepts. The first one was the free concept, in which educational process was identified with the individual's spontaneous, mainly biological development. The second one underlined the social aspect of education or understood education as a result of effects on the individual coming from the environment. In the third one, education was received in a community and in institutions where 


\section{Acta Educationis Generalis \\ volume 9, 2019, issue 1}

personality was shaped by pre-planned, predictable effects (Oelkers, 2000). Now, at the beginning of the 21st century, it seems that norm-critical educational theories formulate valuable sub-goals but they cannot separate from normativity wished to be exceeded.

According to Ruhloff (1979), although the Emancipatory Pedagogy denies most norms, it is against all kinds of power and ideology, still it is built on four dogmas:

1) belief in the senselessness of having power over other people;

2) belief in human history and in the possibility of the evolution of a more perfect rationality;

3) belief in the fact that the requirements of fairness can be achieved if people understand each other;

4) belief in the absolute reason for a democratic turn in history.

Based on Freire (2005) and McLaren (2015), it may seem that the main aim of the empiricist, critical and norm-critical tendencies in pedagogy is creating a scientifically proven educational technology. Although, the necessary conditions here prevail as well:

1) to assess the different behaviors according to criteria, to keep up selection;

2) to give help and points of reference in education while teaching how to live one's life;

3) to explain empirical reality and to trans-illuminate it with thinking.

Therefore, besides applying processes adjusted to the actual pedagogical situation, pedagogy cannot do without an image of a general set of agreed objectives (Hanan, 2008, 2016; Penalva, 2014; Vajda, 2014, 48-53; Jozek, 2015; Krek \& Zabel, 2017). The theoretical and practical tasks of pedagogy are to formulate values to be generalized at the different levels; and to achieve a balance in conforming to external and internal norms in the educational process and to create an innate need for this balance in the individual that is later upheld by self-control. Henceforth, the emphasis is on these two.

\section{Educational values}

Various reasons are offered for the fact that development is unimaginable without teleologicalness. At the same time, it is obvious that moral and educational objectives, depending on the different views on human nature and social expectations, might be valued high or low, and very often are manipulated by the different worldviews (Sáska, 2006). This can be eliminated by interpreting education in an objective, idealistic, value theoretical way. This reveals significant, common and positive elements of the various views and it derives the objective of education from the evaluating conscientiousness of the individual independent from social practices. In the literature (Bábosik, 2000), we can find educational aims that are general, ideologically independent and form the human being into a value-orientated, deliberately moral, independent but social being within the boundaries of education: 


\section{Acta Educationis Generalis \\ volume 9, 2019, issue 1}

1) the ability for self-regulation makes it possible to synchronize the external expectations and the internal needs, intentions;

2) the sense of reality can help the individual to examine and modify already internalized norms according to their experiences in reality;

3) rationality enables the individual to provide reasons for already internalized norms regulating their behavior;

4) sensibility enables one to take into consideration the social consequences of one's deeds and other people's interests, problems and motives.

5) creativity is the ability to develop and refine the system of behavioral norms innovatory and independently;

6) social extensivity makes it possible to generally apply accepted social norms outside the small group, in all other groups as well as;

7) being able to check legitimacy is the ability not just to adapt to normative expectations but to reconsider their grounds.

Two possibilities can be highlighted from the various ways these criteria can be grouped. According to the first grouping, the ability for self-regulation means a human being who conducts life, individual and social activities by inner instincts and ceases to behave according to the situations. The ability of social extensivity and sensibility opens up the possibility to rise above the personal and communal interests, to be selfless and be focused on the community.

The sense of reality, rationality, creativity and being able to check legitimacy all contribute to making it impossible for someone to be manipulated, to pair up self-direction with self-control, where it is essential that self-regulation does not mean that the internalized system of norms should become rigid, functioning purposelessly; but should continuously develop, differentiate and enrich in its elements.

The second grouping helps to dissolve the discrepancy between the purely personal and purely social by pairing up the criteria around one central element: sensibility. The ability for self-regulation and being able to check legitimacy ensures the simultaneous possibilities for stability and improvement and the balance between the internal and external points of reference. The sense of reality and social extensivity contribute to a behavior that is critical, but considers social viewpoints as well. Creativity and rationality harmonize the person's emotional and cognitive dimensions, this way supports the ability of a person to be able to change their social judgments and self-reflection.

These educational objectives do not exclude other positive aims, factors and subgoals such as discipline, helpfulness, openness, cooperation which can be derived from them. In the process of transmitting values, the transitions between them cannot be left out of consideration, more precisely; they are adjusted to the developmental stages and the mode of transmission. 


\section{Acta Educationis Generalis \\ volume 9, 2019, issue 1}

\section{Transition of values}

The existence of control in moral-social behavior and the existence of factors taking place during socialization in a personality, as well as, the development of a moral disposition, were linked to internalizing moral norms and as such were regarded cognitive in nature by the intellectual tendency. Psychoanalysis regarded them as experiential in nature linking it to the internalizing of the moral-social norms of the primary caretakers. Behaviorism regarded them as a characteristic feature based on conditioning and recurrence, so it is an ingrained habit in nature. As we can see from this, psychology described the principles of creating the system of moral criteria controlling behavior with three mechanisms being cognitive, emotional and willful, but in the institutional, value teaching processes, these three features are rarely present at the same time and in equal measures. Cognition, as one of the agents of socialization, became overrated because cognitive sciences were declared to be independent and it was acknowledged that socialization was a complex process that could not be explained only by reflexes and reinforcement. One of the valuable contributions of modern pedagogy is that personal development and the gradual decline of external controls; in other words, the appearance of freedom and responsibility simultaneously and at an equal level; is possible because of a general, and not an exclusively intellectual, maturity of the personality. Reaching it is defined by the road taken from a formally heteronym, externally controlled, impulsiveegocentric-in-content kind of behavior to a formally autonomous, internally controlled, norm-keeping-altruistic-in-content type of principles guiding behavior. Because of this, it is worth considering that:

1) in personal development, a good result comes from a kind of support that keeps in view individual sensibilities on each agent, child developmental stages and all three horizons at the same time;

2) the student is not a passive recipient, in other words, a student is someone who confronts norms already intact, outspokenly or unspoken, as well as, their conscious or unconscious objectives of life by school requirements; what is the source of conflicts between teacher-student, student-institute and the source of mutual socialization; for the educator, it serves as a source of touching the impulses for the future of humans, a source of shaping future based on understanding these impulses (at the same time, performing the descriptive and controlling functions of pedagogy);

3) transmitting values and shaping personality are not the only best, but highranking ways for creating a positive and a generalized feeling of lack; where this feeling of lack means the difference between the child developmental stage and the aim, and the task of pedagogy is resolving this difference (Bábosik et al., 2011);

4) children practice how to keep to social norms and how to cooperate during their public education with far fewer consequences than later in adult life. Along with this, besides ensuring the emotional safety of a child and 


\section{Acta Educationis Generalis \\ volume 9, 2019, issue 1}

promoting harmony between the circumstances and relations, the potential and the task of education are to assist and to urge the student to surpass themselves, which process might involve inner and outer conflicts for the student.

\section{Conclusion}

The possibilities in education and educational affairs in a democratic society are far from being under total control (mechanization) or total self-regulation (atomization). The proportion of being self-regulated and under external sanctions and keeping up a good balance in them are required to be optimal at all levels in the system, regarding the educational values and the transition of values as well. Individuals are not the only sufferers of social integration, and social development does not only emerge on the level of individuals: individual and society are mutually interdependent. For this reason, modern pedagogy simultaneously ensures that: 1) besides shaping personality, students are offered choices; in other words, while conforming to norms, nobody is forced to move away from their own urges, desires, ideals in life; 2) the various outcomes and divergences do not obstruct students from orientating towards a meaningful and constructive activity that is linked to a social subsystem and also from becoming capable of carrying that task out.

\section{References}

Bábosik, I. (2000). Az iskola nevelési hatékonyságának mutatói. Új pedagógiai szemle, 50(4), 3-11.

Bábosik, I., Borosán L., Hunyady Gy., M. Nádasi, M., \& Schaffhauser F. (2011). Pedagógia az iskolában. Budapest: ELTE Eötvös.

Dilthey, W. (1888). Möglichkeit einer allgemeingültigen pädagogischen Wissenschaft. In (1962) Gesammelte Schriften. Band VI., Die Geistige Welt 2. Hälfte. Stuttgart/Göttingen: Vandenhoek und Ruprecht.

Freire, P. (2005). Pedagogy of the oppressed. London: Continuum.

Hanan, A. A. (2008). What is common about common schooling? Rational autonomy and moral agency in liberal democratic education. Journal of Philosophy of Education, 41(4), 609-624. doi: 10.1111/j.14679752.2007.00592.x

Hanan, A. A. (2016). What is critical about critical pedagogy? Conflicting conceptions of criticism in the curriculum. Educational Philosophy and Theory, 50(10), 903-916. doi: 10.1080/00131857.2016.1228519

Jozek, M. (2015). Interpersonal communication in the process of value formation. Acta Technologica Dubnicae, 4(2), 36-42. doi: 10.1515/atd2015-0004 


\section{Acta Educationis Generalis \\ volume 9, 2019, issue 1}

Krek, J., \& Zabel, B. (2017). Why there is no education ethics without principles. Educational Philosophy and Theory, 49(3), 284-293. doi: 10.1080/00131857.2016.1217188

McLaren, P. (2015). Life in Schools. An Introduction to Critical Pedagogy in the Foundations of Education. New York: Routledge.

Mészáros, Gy. (2015). Beilleszkedésre nevelünk?: A társadalmi normák szerepe, változó normák, a normák elnyomó dimenziója, a normakritikus pedagógia. In K. N. Kollár \& N. Rapos, (Eds.), A társas, társadalmi viszonyok (pp. 1320). Budapest: ELTE Eötvös.

Oelkers, J. (2000). Democracy and education: About the future of a problem. In J. Oelkers \& H. Rhyn (Eds.), Dewey and European Education (pp. 3-19). Dordrecht: Springer. doi: 10.1007/978-94-011-4185-7

Penalva, J. (2014). The non-theoretical view on educational theory: Scientific, epistemological and methodological assumptions. Journal of Philosophy of Education, 48(3), 400-415. doi: 10.1111/1467-9752.12087

Ruhloff, J. (1979). Das ungelöste Normproblem der Pädagogik. Eine Einführung. Heidelberg: Quelle und Weyr.

Sáska, G. (2006). Az oktatási ideológiák változékonyságáról: a 19. és a 20. századi liberális oktatáspolitikák. Új pedagógiai szemle, 56(10), 36-55.

Trencsényi, L., \& Nagy, Á. (2016). Tanórán innen, iskolán túl: a szociálpedagógiai gondolat létjogosultsága. Iskolakultúra 26(10), 81-97. doi: 10.17543/ISKKULT.2016.10.81

Vajda, Zs. (2014). A gyermek pszichológiai fejlődése. Budapest: Saxum. 